

\section{Sumário}

I. Crônicas do Direito Internacional ...............................................1

REPARAÇÃo DE VÍTIMAS À LUZ DE UM TRATAdo SOBRE EMPRESAS E DIREITOS HUMANOS ............ 3 Ana Cláudia Ruy Cardia

Consumer Social Responsibility as a Requirement for Corporate Social ResponsibiliTY

Nitish Monebhurrun

Crisis in Venezuela: The Brazilian response to the massive flow of Venezuelans in

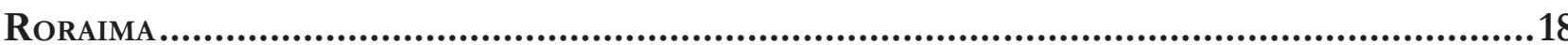

Jacqueline Salmen Raffoul

II. Dossiê EsPecial: Business and Human Rights.........................................23

Some remarks on the third sessions of the Business and Human Rights Treaty Pro-

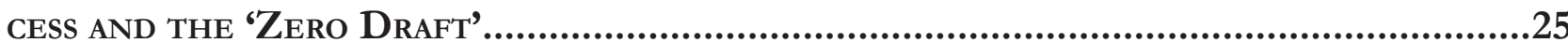

Humberto Cantú Rivera

The United Nations guiding principles on business and human Rights, the State

DUTY TO PROTECT HUMAN RIGHTS AND THE STATE-BUSINESS NEXUS.

Mihaela Maria Barnes

HARdening SOFT LAW: ARE THE EMERging Corporate SOCIAL DisClOSURE LAWS CAPABLE OF GENERATING SUBSTANTIVE COMPLIANCE WITH HUMAN RIGHTS?

Justine Nolan

Del Documento de Elementos al Draft 0: apuntes jurídicos respecto del posible CONTENIDO DEL PROYECTO DE INSTRUMENTO VINCULANTE SOBRE EMPRESAS TRANSNACIONALES

Y OTRAS EMPRESAS CON RESPECTO A LOS DERECHOS HUMANOS

Adoración Guamán 
ACCESS TO REMEDIES AND THE EMERGING ETHICAL DILEMMAS: CHANGING CONTOURS WITHIN THE BUSINESS-HUMAN RIGHTS DEBATE

Justin Jos

LA RESPONSABILIDAD PENAL DE LAS EMPRESAS POR GRAVES VIOLACIONES DE DERECHOS HUMANOS: PRÁCTICA ACTUAL Y DESAFÍOS FUTUROS 130

Daniel Iglesias Márquez

THE ENVIRONMENTAL LAW DIMENSIONS OF AN INTERNATIONAL BINDING TREATY ON BUSINESS AND HUMAN RIGHTS

Juan Gabriel Auz Vaca

Los Objetivos de Desarrollo Sostenible en Europa y su Intersección con el Marco de los Negocios y los Derechos Humanos

Paolo Davide Farah

HumAN RIGHTS AND MARKET ACCESS 203

Danielle Mendes Thame Denny

BusinesS AND HUMAN RIGHTS IN BRAZIL: EXPLORING HUMAN RIGHTS DUE DILIGENCE AND OPERATIONAL-LEVEL GRIEVANCE MECHANiSMS IN THE CASE OF KinRoss PARACATU Gold Mine...222 Mariana Aparecida Vilmondes Türke

Human Rights and eXtractive industries in Latin America: What Responsibility of CORPORATIONS AND THEIR STATES OF ORIGIN FOR HUMAN RIGHTS VIOLATIONS IN THE INTER-American Human Rights System?.

Alberto do Amaral Junior e Viviana Palacio Revello

MultinaCiOnAIS FAST FASHION E DIREITOS HUMANOS: EM BUSCA DE NOVOS PADRÕES DE RESPONSABILIZAÇÃO 255

Laura Germano Matos e João Luis Nogueira Matias

III. Artigos sobre outros temas

EFFICIENCY AND EFFICACY OF PUBLIC FOOD PROCUREMENT FROM FAMILY FARMERS FOR SCHOOL FEEDING IN BRAZIL. 271

Rozane Márcia Triches 
A relaÇão ENTRE O GRAU de INTEGRaÇÃo ECONÔMiCA E O SISTEMA DE SOLUÇÃo DE CONTROvÉRSIAS: UM ESTUdo COMPARATIVO ENTRE A UNIÃo EURopeia E O MERCOSUl.....................286

Luciane Klein Vieira e Elisa Arruda

THE RIGHTS TO MEMORY AND TRUTH IN THE INTER-AMERICAN PARADIGMS OF TRANSITIONAL JUSTICE: THE CASES OF BRAZIL AND CHILE 308

Bruno Galindo

Juliana Passos de Castro

A margem nacional de apreciação na Corte Interamericana de Direitos Humanos.325 Gilberto Schäfer, José Eduardo Aidikaitis Previdellie e Jesus Tupã Silveira Gomes

Novos Direitos FUNDAMENTAIS NO ÂMBITo DA UNASUL: ANÁLISE DAS AGENDAS DE Brasil E VENEZUELA À LUZ DO DIREITO À PAZ.

Pedro Pulzatto Peruzzo e Arthur Ciciliati Spada

A atuação do Grupo Mercado Comum frente À Criminalidade organizada transnacio-

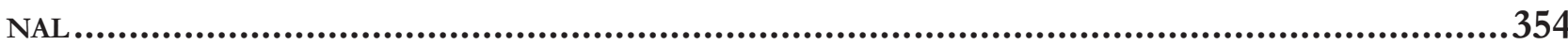

Sabrina Cunha Kesikowski, Luis Alexandre Carta Winter e Eduardo Biacchi Gomes

COUNTER-TERRORISM LEGISLATION AND TERRORIST ATTACKS: DOES HUMAN RIGHTS HAVE SPACE?

Heloisa Tenello Bretas e Daniel Damásio Borges

Territórios da ViolênCia de GÊNERo: NORMATIVA INTERNACIONAL E os Casos "CAMpo AlGodoeiro” (MÉXICO) - “Morro do Garrote” (BrasiL)

Eugênia Nogueira do Rêgo Monteiro Villa e Bruno Amaral Machado

O USO DE MECANISMOS INFORMAIS DE GOVERNANÇA GLOBAL E SUA APLICABILIDADE NAS LICITAÇÕES PÚBLICAS BRASILEIRAS.

Fabiano de Figueiredo Araujo e Paulo Afonso Cavichioli Carmona

Autonomia INSTITUCIONAL DA IGREJA CATÓliCA E A INGERÊNCIA INDEVIDA DO ESTADO BRASILEIRo POR EVENTUAIS Ilícitos CANÔNicos: ANÁlise do CASO de Formosa-GO, À luz do TraTADo Brasil-Santa SÉ de 2010 
A MORE TARGETED APPROACH TO FOREIGN DIRECT INVESTMENT: THE ESTABLISHMENT OF SCREENING SYSTEMS ON NATIONAL SECURITY GROUNDS

Carlos Esplugues Mota

IV. RESENHAS 467

Direito Internacional em Perspectiva Transcivilizacional de Yasuaki Onuma........469 Arthur Roberto Capella Giannattasio

Resenha do livro Space, Global Life: The Everyday Operation of International LaW and Development, de Luis Eslava .473

Matheus Gobbato Leichtweis

QUEM TEM MEDO DO PÓS-COLONIAL NO DIREITO INTERNACIONAL? UMA RESENHA DE "DECOLONISING INTERNATIONAL LAW: DEVELOPMENT, ECONOMIC GROWTH AND THE POLITICS OF UNIVERSAlity" de Sundhya Pahuja

Gabriel Antonio Silveira Mantelli

Direitos humanos COMO UM NOVO PROJETO PARA O Direito INTERNACIONAL? Notas sobre The Last Utopia, de Samuel Moyn .490 João Roriz 


\title{
Crisis in Venezuela: The Brazilian response to the massive flow of Venezuelans in Roraima
}

\author{
Jacqueline Salmen Raffoul*
}

On a daily basis, thousands of Venezuelans are forced to leave their country as a result of the political and economic crisis. The lack of basic supplies, such as medicine and food, the lack of freedom, due to an authoritarian government, and the soaring crime rates led to a massive movement toward neighboring countries, like Brazil and Colombia.

The inflation rate ${ }^{1}$ of $13,860 \%$, in April of 2018, can easily demonstrate the unprecedented economic crisis of Venezuela. In 2017, while the monthly minimum wage was approximately 200,000 Bolivares, the estimative of the price of basic groceries was around 1,000,000 Bolivares ${ }^{2}$. Hence, it became impossible for most people to provide for themselves and their families.

Besides, the International Community demonstrates continuous concerns regarding the local respect for human rights. In May 2018, the United Nations High Commission for Human Rights considered that there was no political or social condition to carry on the elections in Venezuela. Thus, the United Nations refused to send an international observer to the elections.

Due to the lack of political, social and economic condition, there is a massive flow of Venezuelans in the State of Roraima due to the shared border with Brazil. Forced by the circumstances, leaving their country seems to be a matter of survival. Although Brazil has a positive open door policy, the issues faced by Venezuelans put it in check.

In May of 2018, I visited Boa Vista in order to interview Venezuelan refugees, local people, Government authorities and representatives of international organizations. The results of my research are reported in this chronicle as an attempt to share the Brazilian response to the massive flow of Venezuelans there.

\section{The increasing Refugee status requests from VenezUelans IN RORAIMA}

Considering the situation, expressive amounts of Venezuelans seek the refugee status in other countries. According to the 1951 Convention, a refugee is a person who was forced to move to another country due to well-founded fear of being persecuted for reasons of race, religion, nationality, membership of a particular social group or political opinion. In addition, persecution could also be other human rights violations related to the mentioned reasons ${ }^{3}$.

1 INTERNATIONAL MONETARY FUND. Inflation rate, average consumer prices. Available at < http://www.imf.org/external/datamapper/PCPIPCH@WEO/WEOWORLD/VEN > . Accessed on 21 June 2018.

2 CENDAS-FVM, Sary Levy, professor at the Central University of Venezuela. Bolivares is the current Venezuelan currency.

3 UNITED NATIONS REFUGEE AGENCY: Handbook on Procedures and Crite-

Master of Law student at Centro Universi-
tário de Brasília. E-mail: jsalmenraffoul@gmail. com 
In Brazil, the requests for refugee status from Venezuelans have significantly raised. In 2010, there were only four requests. However, the number has increased and, in 2017, almost 18,000 Venezuelans applied for refugee status, which represented more than half of all the requests in the last year. Most of them were made in Boa Vista ${ }^{4}$.

As Roraima and Venezuela share a common border, the latter is being crossed by a massive flow of Venezuelans. The Brazilian Federal Police estimates that there are currently almost 50,000 Venezuelans in Roraima ${ }^{5}$. In the last five months, the daily average entrance ${ }^{6}$ was around 416 there. Nevertheless, not all of them applied for the refugee status.

According to a mapping carried out, from May 28 until June 9 of 2018, by the municipal government of Roraima, there are currently 25,000 Venezuelans living in Boa Vista ${ }^{7}$. The of entries on the Brazilian soil from January to May of 2018 was 55\% higher than in whole past year, which demonstrates a constant increase ${ }^{8}$.

In order to understand the impact, it is necessary to mention the main features of the State of Roraima. In spite of a territory, which extends up to $224,300 \mathrm{~km}^{2}$, there are only 15 cities in the whole State. The total population is approximately of 522,636 people ${ }^{9}$ and most of them, around 332,020, live in Boa Vista ${ }^{10}$. For such

ria for Determining Refugee Status under the 1951 Convention and the 1967 Protocol relating to the Status of Refugees. Available at < http://www.unhcr.org/4d93528a9.pdf > . Accessed on 20 June 2018.

4 MINISTÉRIO DA JUSTIÇA: Refúgio em números $-3^{\circ}$ edição. Available at: <http://www.justica.gov.br/news/de10-1-mil-refugiados-apenas-5-1-mil-continuam-no-brasil/refugioem-numeros_1104.pdf/view >. Accessed on 20 May 2018.

5 CASA CIVIL: Polícia Federal - Migração em Roraima - 9 de maio de 2018. Available at < http://www.casacivil.gov.br/operacao-acolhida/documentos/policia-federal-migracao-em-roraima9-de-maio-de-2018/view>. Accessed on 20 June 2018.

6 PREFEITURA BOA VISTA: Prefeita apresenta resultado do mapeamento de venezuelanos que vivem em Boa Vista. Available at: < https://www.boavista.rr.gov.br/noticias/2018/06/ prefeita-apresenta-resultado-do-mapeamento-de-venezuelanos-quevivem-em-boa-vista>. Accessed on 20 June 2018.

7 The mapping did not differentiate migrant and refugee.

8 PREFEITURA BOA VISTA: Prefeita apresenta resultado do mapeamento de venezuelanos que vivem em Boa Vista. Available at: < https://www.boavista.rr.gov.br/noticias/2018/06/ prefeita-apresenta-resultado-do-mapeamento-de-venezuelanos-quevivem-em-boa-vista>. Accessed on 20 June 2018.

9 INSTITUTO BRASILEIRO DE GEOGRAFIA E ESTATÍSTICA. Available at: < https://cidades.ibge.gov.br/brasil/rr/panorama>. Accessed on 20 June 2018.

10 INSTITUTO BRASILEIRO DE GEOGRAFIA E ES- reason, 25,000 new people in the city is a significant quantity and the consequences are easily noted.

\section{The difficulties faced by Venezuelans in BOA VISTA}

The economy of Roraima is unable to generate as many jobs as necessary to employ all the Venezuelans arriving daily. Through the whole city of Boa Vista, it is possible to see men in the traffic lights holding signs to show that they are looking for a job. Meanwhile, Venezuelan mothers and their children are begging all over the city.

Even though many of them have higher education degrees, the circumstances led some to accept jobs they would never think of. It is not uncommon to know that Venezuelans accept job positions paid illegally less than a minimum wage. Such situation creates even more hostility towards some Brazilians, who feel that foreigners are stealing their jobs.

In fact, there is a limited amount of job vacancies and an increasing number of people arriving daily looking for jobs in order to rebuild their lives. Unfortunately, this reality creates an unprecedented inexpensive workforce in Roraima and leaves room for different sorts of exploitation.

There is a neighborhood in Boa Vista where Venezuelan women work as prostitutes. Due to the value usually charged, the neighborhood is known as "ochentas" (eighty in Spanish). Besides, cases of slave-like work conditions are also a reality in Roraima, especially in the rural area. For such reason, Federal Government and the Labor Public Attorney's Office have discussed measures to prevent the recruiting of Venezuelans in order to submit them to labor analogous to slavery ${ }^{11}$.

Thus, the positive open door refugee policy of Brazil collides with the daily difficulties faced by Venezuelans in their new country. Notwithstanding the well-known Brazilian hospitality, the cases of xenophobia in Boa Vista has brought some nuance to this cultural

TATÍSTICA. Available at: < https://cidades.ibge.gov.br/brasil/rr/ boa-vista/panorama>. Accessed on 20 June 2018.

11 MINISTÉRIO PÚBLICO DO TRABALHO. Available at $<$ http://portal.mpt.mp.br/wps/portal/portal_mpt/mpt/sala-imprensa/mpt-noticias/6c5a7442-ccb8-4f12-a161-9947a27b7535>. Accessed on 4 September 2018. 
feature. In February of 2018, a man threw an incendiary device at a building occupied by Venezuelans. In the same month, an intentional fire in a house inhabited by more than 10 Venezuelans injured a family, including a four- year- old child.

Furthermore, the gaps between Brazilians and Venezuelans are deepened by their lack of integration in the domestic society. Most Venezuelans live in refugee shelters and, consequently, do not often interact with Brazilians. Even though Spanish and Portuguese may be similar, the learning process is not effortless and is even more difficult due to the lack of interaction between the two peoples

Resultantly, the unemployment issue emerges again. Without speaking Portuguese, the possibility to be hired remains even remoter. Without a job position, it is even more complicated to leave the refugee shelters and provide for themselves and their families.

In this regard, another difficulty arises due to the family separation. Frequently, the plan is for one or a few family members to cross the border first and, after having settled, to bring the others who remained in Venezuela. For this reason, it is appealing for some to remain in Roraima, instead of moving to other states in Brazil.

Moreover, another problem faced is the lack of documents. As previously mentioned, the majority of people seeking refuge are Venezuelans and this situation usually compels them to leave their country without enough time to prepare. A life in a new country without the necessary documents is unconceivable.

Despite all the difficulties, the situation is not hopeless or unchangeable, considering the efforts made by the Government, organizations of the civil society, and International Organizations in order to resettle Venezuelans in Brazil. Surely, there are uncountable challenges, especially because this is an unprecedented situation. However, there are prepared and willing people to offer help and, consequently, hope for the ones who most need it.

\section{The positive actions toward Venezuelans IN RORAIMA}

In view of the challenges faced by Venezuelans and by the State of Roraima, in 2018, the Federal Government stepped in to offer support. One relevant measure was the implementation of the control of the entry and exit at border crossing points, with the assistance offered by refugee shelters placed on the border, organized by the military and with the aid of the United Nations High Commissioner for Refugees (UNHCR).

Therefore, in order to substantiate such actions, the most important legal measures toward Venezuelans were (i) the Decree No. 9285/2018, which recognizes vulnerability of migrants fleeing the humanitarian crisis in Venezuela ${ }^{12}$; (ii) Decree No. 9286/2018, which defines the composition, competencies and operating rules of the Federal Committee of Emergency Assistance for the reception of vulnerable migrants ${ }^{13}$; and (iii) the Provisional Measure No. 820/2018, converted into the Statute no. 13,684/2018, which provides for emergency assistance measures for the reception of people in a vulnerable situation deriving from the migratory flow caused by the Venezuelan crisis ${ }^{14}$.

Since the recognition of the vulnerability of the Venezuelans by the Decree No. 9285/2018, the Statute No $13,684 / 2018$ designed actions that are more specific in order to implement social protection. According to this law, the definition of social protection regards "structured public policies to prevent and remediate situations of social vulnerability and personal risk that imply in the violation of human rights". The Government - at the federal, district and municipal levels - should carry on the public policies with organizations of civil society as well.

In fact, Government, organizations of civil society and International Organizations are already working together. In the refugee shelters, the military have been working with the UNHCR in the organization of such places. The support given by the military has improved the logistic of supplies and the health care. For instance, in Boa Vista, in April of 2018, the military sanitized a

12 CÂMARA DOS DEPUTADOS. Available at < http:/ /www2. camara.leg.br/legin/fed/decret/2018/decreto-9285-15-fevereiro2018-786170-publicacaooriginal-154864-pe.html>. Accessed on 30 June 2018.

13 CÂMARA DOS DEPUTADOS. Available at <http://www2. camara.leg.br/legin/fed/decret/2018/decreto-9286-15-fevereiro2018-786171-norma-pe.html>. Accessed on 30 June 2018.

14 PRESIDÊNCIA DA REPÚBLICA. Available at < http:// www.planalto.gov.br/ccivil_03/_ato2015-2018/2018/Lei/L13684. htm>. Accessed on 30 June 2018. 
gymnasium in order to revert the hazardous conditions found there due to the overcrowding of Venezuelans.

Nevertheless, the Public Prosecutor's Office has inspected the conditions of the shelters in order to verify the respect of human rights. In May of 2018, a report regarding the shelters was drafted and recommendations were made to improve the situation of the Venezuelans. In such occasion, the Public Prosecutor's Office observed that the shelters with indigenous Venezuelan population, in Pacaraima, had the worst condition. This shelter is especially challenging due to the quantity of Venezuelans arriving daily.

The Venezuelan indigenous population is the most vulnerable and demands especial care. The act of feeding, for instance, has its own particularities. They are used to prepare their own food, which can be an issue in a shelter with hundreds of people. In addition, they have food restrictions that may seem unusual to non-indigenous people.

Furthermore, the Public Defender's Office offers legal assistance to the ones - Brazilians or foreigners - who are not able to afford legal services. Thus, in 2017, the Public Defender's Office and the Public Prosecutor's Office filed a Public Civil Action before the Federal Court in order to request the waiver of the payment of the fees charged for granting temporary residence for needy Venezuelan immigrants in Brazil.

Despite these measures, the civil society and other organizations have played in important role. A Catholic Church in Boa Vista, the Consolata, has opened its doors to Venezuelans to live there. With the support of UNHCR and the military, a shelter was settled in the backyard and families were welcomed and accommodated. They are able to use the structure of the Church and the members also support them with donations.

In a similar vein, there are non-governmental organizations (NGOs) that develop aid actions in the assistance of Venezuelans. The NGO "Los Hermanos", created by two friends, a lawyer and a doctor, helps Venezuelans in Boa Vista with donations and food twice or three times a week. They have a team of volunteers and work in the integration of the Venezuelans in the new city. In addition, the NGO has been working in the creation of a new shelter, supported by UNHCR and another International Organization, the International Humanitarian Federation, with a project to improve the installations of the building.
In view of the actions, the articulation of public policies by the Government with other organizations may be an adequate way to approach the situation. As the numbers show, the flow of Venezuelans is still increasing in the State of Roraima. For this reason, the participation of different sectors of society is essential to provide the best possible outcome.

\section{Final considerations}

All the positive actions listed are samples of the current initiatives in Roraima. It is clear that each one has its own importance. As the challenges are countless, the support of different entities provides actions backed by solid knowledge in their respective fields. Thus, the articulated polices among different entities seem to be the most successful resource for Roraima and Venezuelans as well.

Nevertheless, the broad terms used in the legislation regarding Venezuelans created an unclear scenario that could interfere in the proper articulation of public policies. The terms used to describe the migratory flow are vague, as they do not distinguish between refugee seekers and migrants. Legally speaking, both concepts are completely different.

In the first case, refugee seekers do not voluntarily move to another country, but they are forced to run from the well-founded fear of being persecuted for reasons for race, religion, nationality, membership of a particular social group or political opinion, or by other related human rights violation. Meanwhile, migrants voluntarily move, usually to other countries, for any particular reason. For instance, the motivation could be a better life abroad or to join family members.

In the case of Venezuelans, crossing borders to Brazil usually is a matter of survival, not a voluntary decision. Life in their country turned out to be impossible due to the continuous human rights violations. The Statute No. 13,684/2018 recognizes such facts by the definition given to "humanitarian crisis", which is described as a situation of, among other possibilities, "widespread violation of human rights or international humanitarian law that causes a disorderly migratory flow toward the region of the national territory". However, there is no specific term regarding refugee seekers. 
Finally, the distinguishing terms would be useful for Venezuelans and for Brazil as well. The responsibility of a country is different regarding, on one hand, migrants and refugee seekers, on the other hand: the rights of refugee seekers are broader than the rights of migrants. Even though the inaccuracy of the terms could be intentional, a clear position would be an important step in the defense of human rights, as it would allow a better planning of public policies to efficiently approach the situation. 
Para publicar na Revista de Direito Internacional, acesse o endereço eletrônico www.rdi.uniceub.br ou www.brazilianjournal.org.

Observe as normas de publicação, para facilitar e agilizar o trabalho de edição. 